\title{
Perancangan dan Pembuatan Sistem Monitoring Suhu Ayam, Suhu dan Kelembaban Kandang untuk Meningkatkan Produktifitas Ayam Broiler
}

\author{
Ganjar Turesna, Drs., M.T. \\ Fakultas Teknik, Jurusan Teknik Elektro \\ Universitas Langlangbuana \\ turesna2901@gmail.com \\ Sutisna Abdul Rahman, S.T., M.T. \\ Fakultas Teknik, Jurusan Teknik Elektro \\ Universitas Langlangbuana \\ sutisnaar@gmail.com
}

\author{
Andriana, S.T., M.T. \\ Fakultas Teknik, Jurusan Teknik Elektro \\ Universitas Langlangbuana \\ andriana6970@gmail.com \\ Muhamad Ripa Nawa Syarip \\ Fakultas Teknik, Jurusan Teknik Elektro \\ Universitas Langlangbuana \\ muhamadriva8@gmail.com
}

\begin{abstract}
Abstrak - Ayam dapat berproduksi secara optimum bila faktor-faktor internal dan eksternal berada dalam batasanbatasan yang normal sesuai dengan kebutuhan hidupnya. Suhu lingkungan merupakan salah satu faktor eksternal yang dapat mempengaruhi produktivitas ayam. Suhu panas pada suatu lingkungan pemeliharaan ayam telah menjadi salah satu perhatian utama karena dapat menyebabkan kerugian ekonomi akibat peningkatan kematian dan penurunan produktivitas. Kandang sistem tertutup atau closed house merupakan sistem kandang yang harus sanggup mengeluarkan kelebihan panas, kelebihan uap air, gas-gas yang berbahaya seperti $\mathrm{CO}, \mathrm{CO}^{2}$ dan $\mathrm{NH}^{3}$. Alat ini terdiri dari beberapa perangkat keras dan lunak, diantaranya : Sensor Suhu DS18B20 sebagai pendeteksi suhu pada kandang ayam broiler, sensor kelembaban DHT11 sebagai pendeteksi kelembaban pada kandang ayam broiler, sensor far infra red MLX90640 sebagai pendeteksi suhu tubuh ayam, Wemos D1 mini sebagai mikrokontroler sekaligus komunikasi data melalui wifi ESP8266, Relay sebagai pemutus aliran listrik AC, lampu pijar sebagai pemanas kandang, blower/fan sebagai pendingin kandang, mist maker sebagai pelembab kandang dan arduino IDE sebagai software yang digunakan untuk memprogram. Alat ini melakukan monitoring dengan parameter suhu kandang, kelembaban kandang dan suhu tubuh ayam yang dikirim melalui wifi ke server peternak, namun jika suhu kandang $<24^{\circ} \mathrm{C}$ maka pemanas yang akan secara otomatis menyala tapi jika suhu kandang $>29^{\circ} \mathrm{C}$ maka blower/fan yang akan menyala secara otomatis dan jika kelembaban kandang $<60 \%$ maka sirkulasi akan menyala secara otomatis tapi jika kelembaban kandang $>70 \%$ maka mist maker yang akan menyala secara otomatis. Dengan dibuatnya alat ini, dapat memudahkan peternak untuk memonitoring suhu ayam, suhu kandang dan kelembaban kandang sehingga produktifitas ayam broiler stabil dan hasilproduksi ayam yang tepat waktu serta efektif.
\end{abstract}

Kata kunci: kandang sistem tertutup, closed house, DS18B20, DHT11, MLX90640

\section{Pendahuluan}

Ayam broiler merupakan jenis ayam hasil dari budidaya teknologi peternakan yang memiliki ciri khas pertumbuhan yang cepat, sebagai penghasil daging dengan konversi pakan yang rendah dan siap dipotong pada usia 28-45 hari. Dalam beternak ayam yang perlu diperhatikan antara lain pemberian pakan ayam yang seimbang dan suhu kandang ayam yang sesuai. Broiler memiliki kelebihan dan kelemahan. Kelebihannya adalah dagingnya empuk, ukuran badan besar, bentuk dada lebar, padat, dan berisi serta pertumbuhannya yang relatif cepat. Sedangkan kelemahannya adalah memerlukan pemeliharaan secara intensif dan cermat, relatif lebih peka terhadap suatu infeksi penyakit dan sulit beradaptasi (Murtidjo, 1992). Pertumbuhan yang paling cepat terjadi sejak menetas sampai umur 4--6 minggu, kemudian mengalami penurunan dan terhenti sampai mencapai dewasa (Kartasudjana dan Suprijatna, 2005).

Gangguan pertumbuhan ini terkait dengan penurunan konsumsi pakan dan peningkatan konsumsi air minum selama ayam mengalami suhu panas. Dalam rangka menjawab tantangan tersebut, peternak ayam diharuskan memilih cara-cara yang tepat guna untuk pemeliharaan ayam.

Cara-cara itu antara lain cara pemilihan lahan, pembuatan kandang, cara pemberian pakan, cara pembersihan kandang. Salah satu solusi untuk mengatasi permasalahan tersebut adalah pemanfaatan teknologi.

Selain itu permasalahan lain yang dialami oleh para peternak ayam yaitu ketika si peternak memiliki lahan peternakan yang jauh dari tempat tinggalnya, sehingga membuat si peternak tersebut harus bolak-balik untuk 
melihat kondisi peternakannya ataupun membuat peternak ayam menyewa banyak karyawan untuk mengurusi peternakannya terutama anak ayam yang masih berumur kurang dari 1 minggu, sehingga akan berdampak pada berkurangnya pendapatan tiap bulannya.

Oleh karena itu, penulis mencoba untuk merancang dan membuat suatu kandang ayam dengan sistem close house yang nantinya suhu tubuh ayam broiler serta suhu dan kelembaban lingkungan kandang akan bisa di monitoring oleh pemilik/peternak, ditambah pemilik/ peternak dapat mengetahui pada saat ayam broiler tersebut mati atau hilang dengan diperingati oleh buzzer.

\section{Metode}

\subsection{Perancangan Alat}

Pembuatan alat ini diperlukan perancangan dari sisi hardware dan software. Komponen elektronik yang diperlukan yaitu Sensor MLX90640, Sensor Kelembaban DHT11, Sensor Suhu DS18B20, Wemos D1 Mini, Fan/Blower 5V, Lampu Pijar 5 Watt, Mist Maker, dan Arduino IDE, Wamp Server sebagai programnya. Ada pun blok diagram alat rancangannya adalah sebagai berikut:

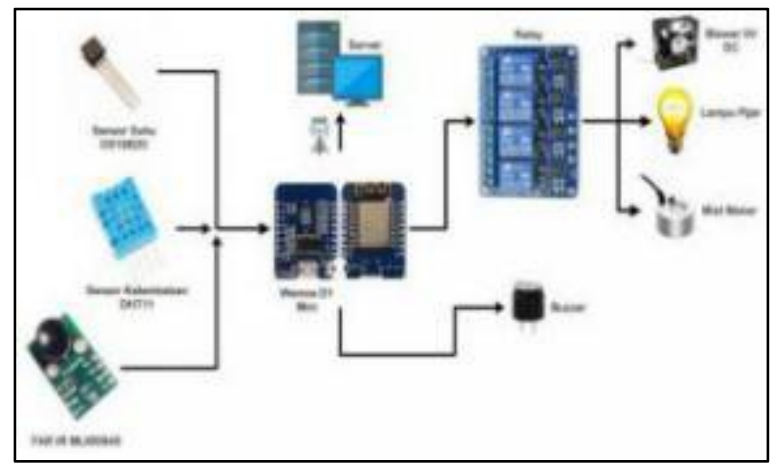

Gambar 1 Blok Diagram Alat

\subsection{Perancangan Perangkat Lunak}

Dalam perancangan perangkat lunak untuk menunjang fungsi alat ini, maka dibuatlah flowchart/diagram alir untuk memudahkan perancangan.

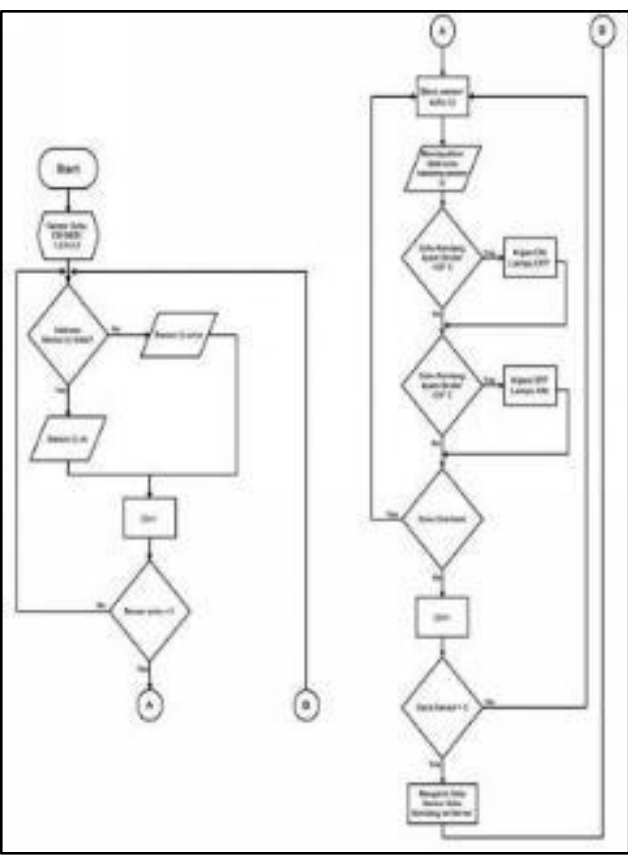

Gambar 2 Flowchart Sensor Suhu DS18B20

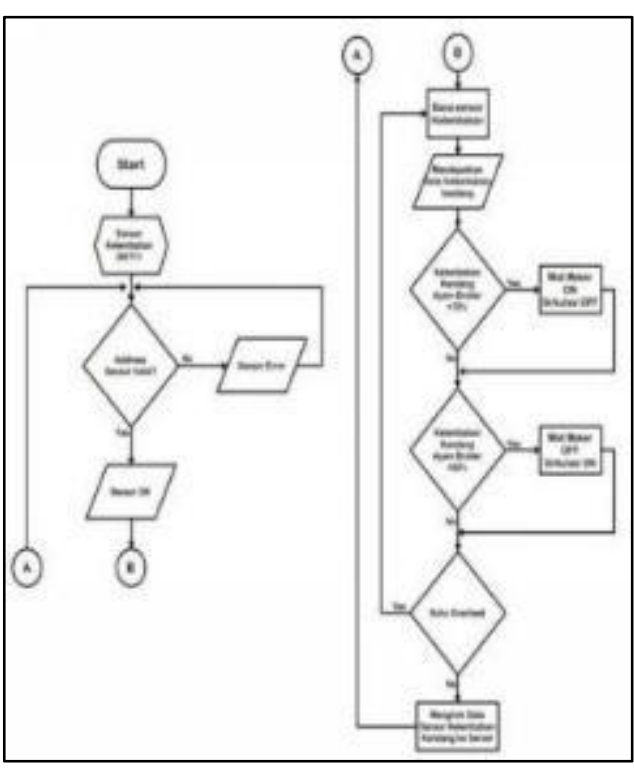

Gambar 3 Flowchart Sensor Kelembaban DHT11 


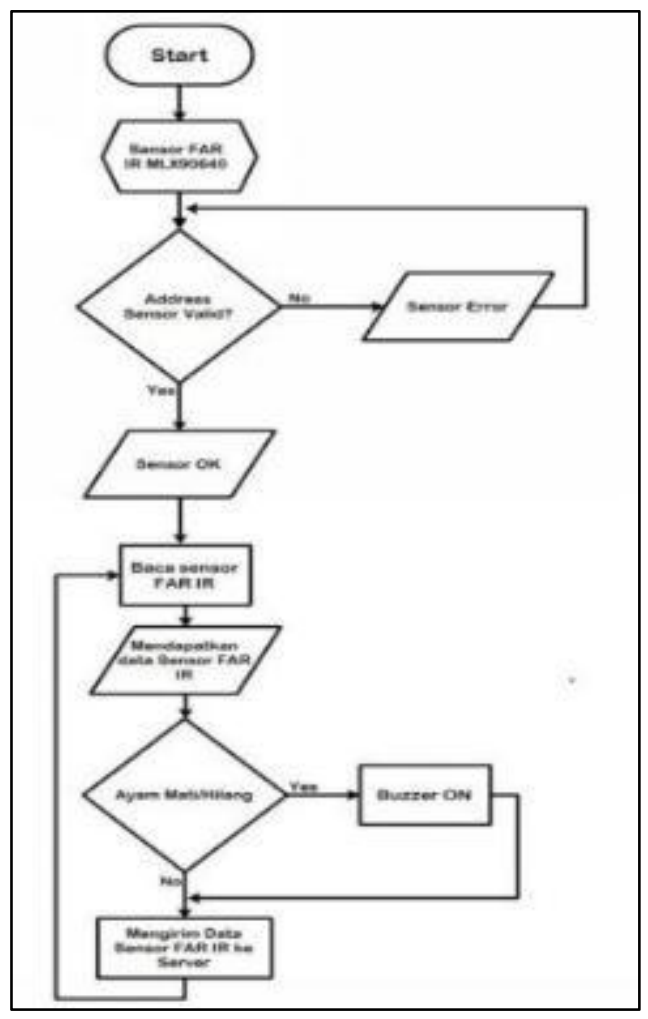

Gambar 4 Flowchart FAR IR MLX90640

Secara garis besar prinsip kerja dapat dijelaskan dengan langkah-langkah sebagai berikut.

1. Hidupkan alat dengan menghubungkan adaptor alat, lampu pijar, blower, dan mist maker.

2. Sensor DS18B20 dan DHT11 akan membaca ada dan tidaknya alamat/address. Jika ada alamat/address maka akan langsung mendeteksi sensor namun jika tidak ada alamat/address maka akan terus kembali mencari/return.

3. Proses data input dari sensor DS18B20 dan DHT11 berupa data suhu dan kelembaban masuk kedalam Wemos D1 Mini.

4. Wemos D1 Mini akan mengolah data input dari sensor suhu DS18B20 jika terdeteksi suhu kandang mengalami penurunan atau kenaikan maka akan melakukan kondisin dibawah ini :

$>$ Jika suhu kandang $>29^{\circ} \mathrm{C}$ : Blower ON dan Lampu Pijar OFF

$>$ Jika suhu kandang $<24^{\circ} \mathrm{C}$ : Blower OFF dan Lampu Pijar ON

Untuk pengolahan data input sensor kelembaban DHT11 jika terdeteksi kelembaban kandang mengalami kenaikan kenaikan dan penurunan maka akan melakukan kondisi dibawah ini :

$>$ Jika kelembaban kandang $>70 \%$ : Mist Maker ON Sirkulasi OFF

$>$ Jika kelembaban kandang $<60 \%$ : Mist Maker OFF Sirkulasi ON
Untuk pengolaha data input sensor FAR IR MLX90640 jika terdeteksi suhu tubuh ayam maka akan langsung mengirim data suhu tubuh ayam tersebut ke server, namun jika terdeteksi ada kehilangan dan kematian pada ayam akan ada suara peringatan.

\section{Hasil dan Diskusi}

Dalam hal ini akan dibahas mengenai pengujian dan analisis terhadap bagian-bagian dari sistem dan pengujian terhadap cara kerja sistem secara keseluruhan. Adapun tujuannya adalah untuk analisa lebih detail apakah hasil pengujian dari bagian-bagian tersebut sudah berfungsi dengan benar. Adapun bagian-bagian yang akan dilakukan pengukurandan diuji adalah fungsi-fungsi sebagai berikut :

1. Pengujian \& Analisis Sensor Suhu DS18B20

2. Pengujian \& Analisis Sensor Kelembaban DHT11

3. Pengujian \& Analisis Sensor Far Infra Red MLX90640

4. Pengujian \& Analisis Wemos D1 Mini

5. Pengujian \& Analisis Relay

\subsection{Pengukuran dan Pengujian Sensor}

Pengukuran dan pengujian ini dilakukan untuk mengetahui sensitifitas sensor yang akan digunakan antara lain :

\subsubsection{Sensor Suhu DS18B20}

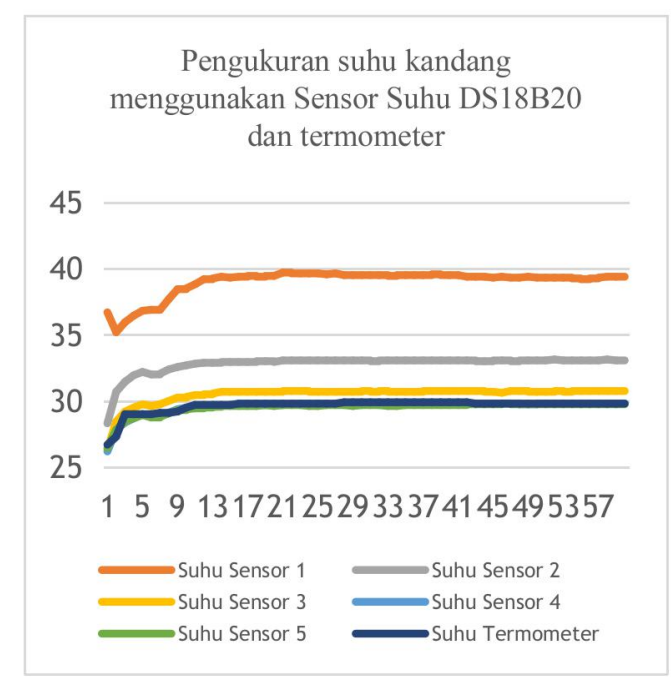

Gambar 5 Pengukuran suhu kandang menggunakan Sensor Suhu DS18B20 dan thermometer

Dari hasil pengujian pada gambar 5 diatas bisa diketuhui bahwa ada 5 sensor suhu DS18B20 dan 1 buah termometer ruangan pada kandang ayam tersebut. Sensor 1 itu dikhususkan untuk melihat suhu pada box pemanas, sensor 2 itu dilakukan ntuk 
melihat keluaran hembusan panas dalam box pemanas, dan untuk sensor 3, 4, dan 5 untuk melihat suhu pada kandang ayam dan thermometer ruangan itu diletakan pada bagian tengah atas. Pada pengujian yang sudah dilakukan terdapat beberapa perbedaan suhu dalam kandang ayam namun selisih antara sensor suhu DS18B20 dengan thermometer itu paling banyak hanya $0.1^{\circ}$ Celcius.

\subsubsection{Sensor Kelembaban DHT11}

Sebagai pembanding keakuratan data pengukuran sensor kelembaban DHT11 digunakan data hasil penelitian Chandra Gusti Nanda Putra dengan judul Otomasi Kandang Dalam Rangka Meminimalisir Heat Stress Pada Ayam Broiler Dengan Metode Naive Bayes. (https://docplayer.info/62501069-Otomasikandang-dalam-rangka meminimalisir-heat-stresspada-ayam-broiler-dengan-metode-naive-bayes.html)

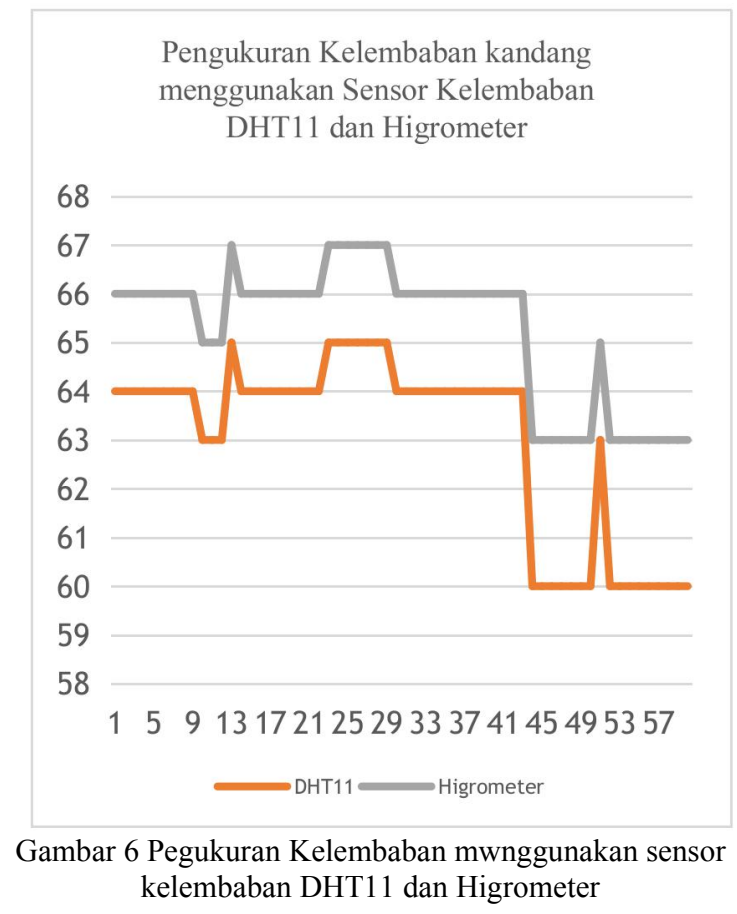

Dari hasil pengujian pada gambar 6 diatas bisa diketuhui bahwa ada 1 sensor kelembaban DHT11 pada kandang ayam tersebut. Sensor kelembaban DHT11 diletakan pada bagian tengah atas untuk melihat kelembaban pada kandang ayam. Pada pengujian yang sudah dilakukan terdapat beberapa perbedaan kelembaban dalam kandang ayam namun selisih antara sensor kelembaban DHT11 dengan higrometer itu sekitar 3\%.

\subsubsection{Sensor FAR IR MLX90640}

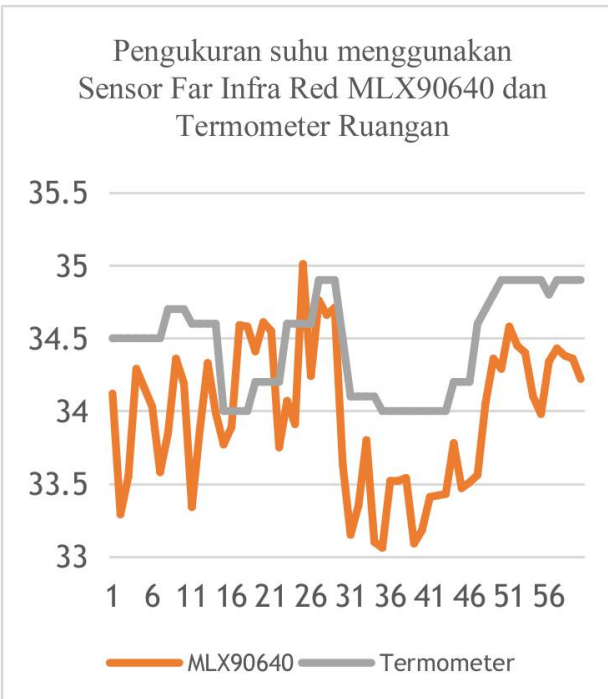

Gambar 7 Pengukuran suhu menggunakan Sensor Far Infra Red MLX90640 dan Termometer ruangan

Dari hasil pengujian pada gambar 7 diatas bisa diketuhui bahwa ada 1 sensor Far Infra Red MLX90640 dan 1 buah thermometer ruangan pada kandang ayam tersebut. Sensor Far Infra Red MLX90640 diletakan pada bagian tengah atas untuk melihat suhu yang berada pada kandang ayam. Pada pengujian yang sudah dilakukan terdapat beberapa perbedaan suhu dalam kandang ayam tersebut namun selisih antara sensor far infra red MLX90640 dengan Termometer itu paling beasar sekitar $0,7^{\circ} \mathrm{C}$.
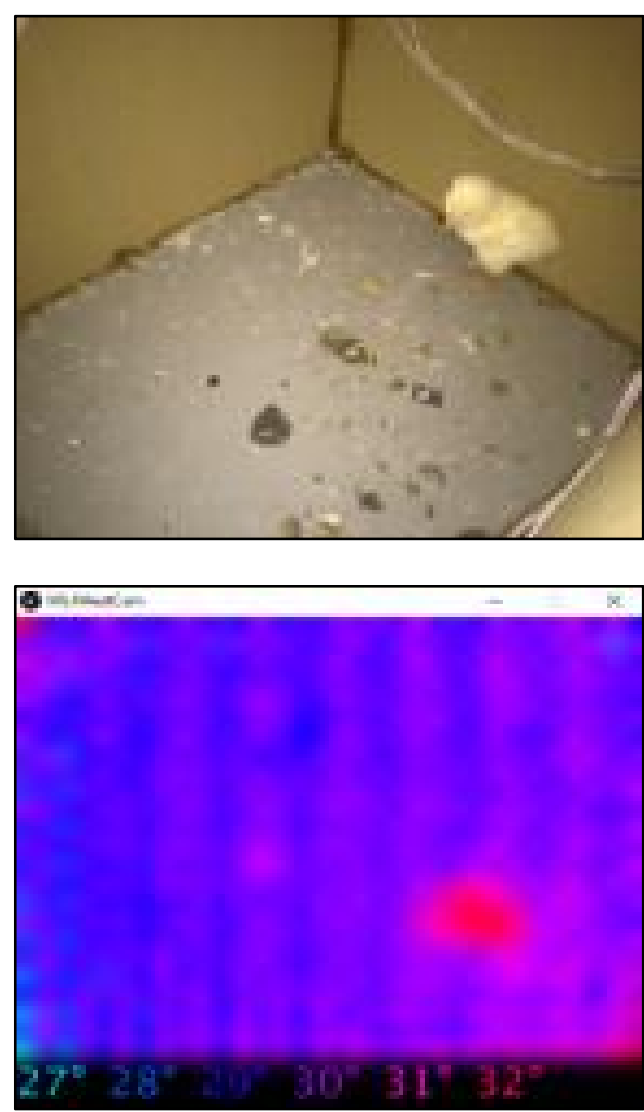

Gambar 8 Monitor Far Infra Red MLX90640 dengan 1 ayam 

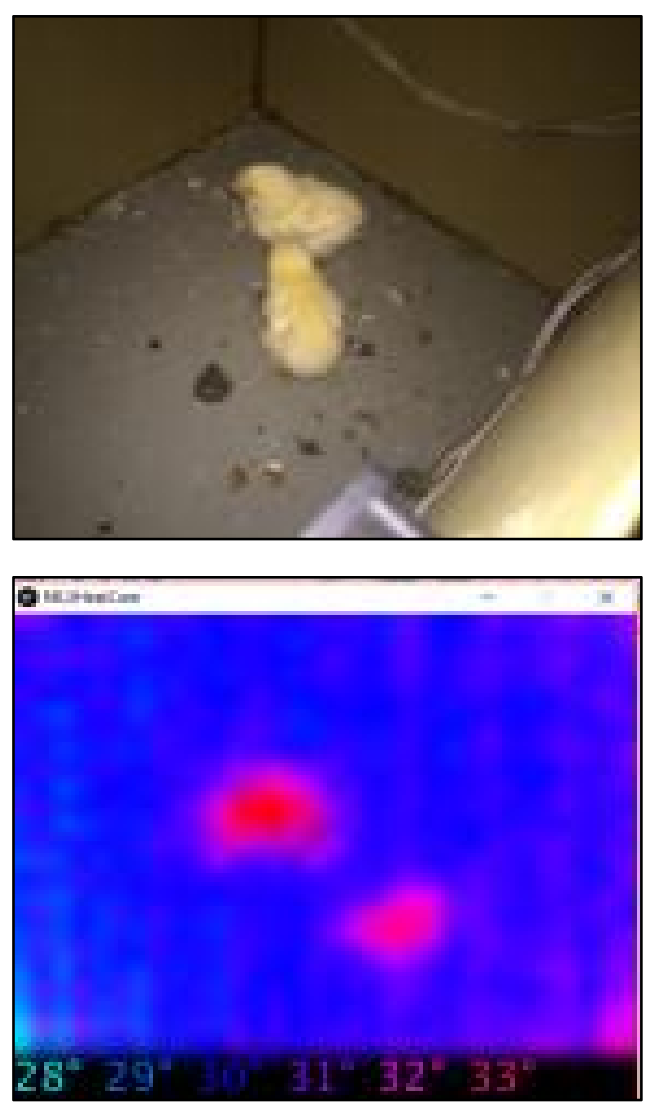

Gambar 9 Monitor Far Infra Red MLX90640 dengan 2 ayam
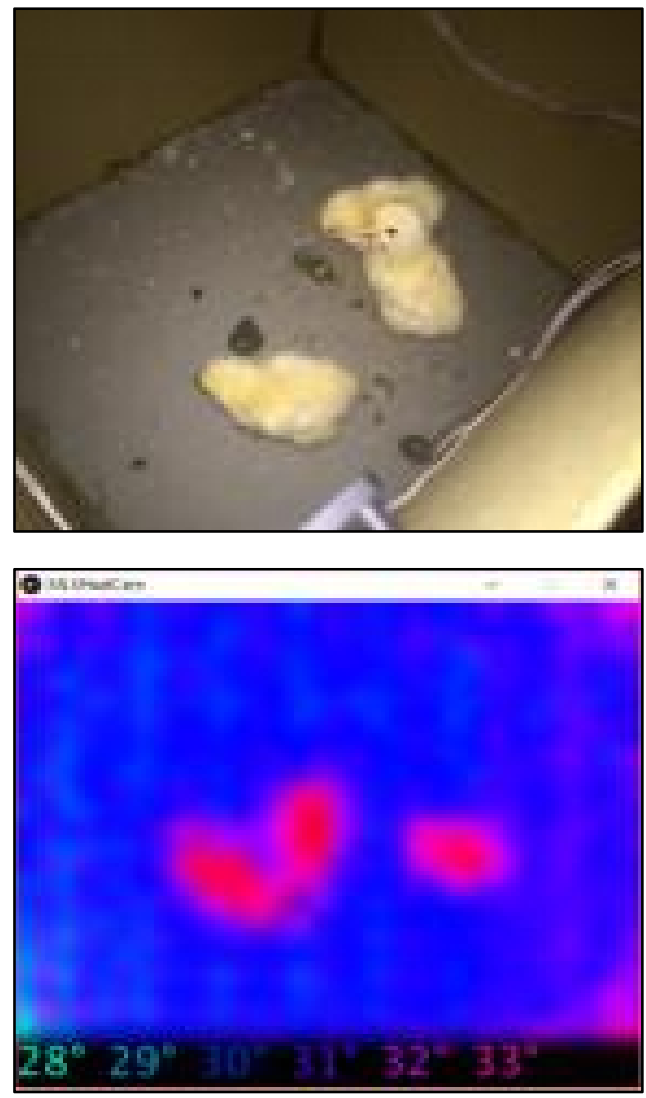

Gambar 10 Monitor Far Infra Red MLX90640 dengan 3 ayam
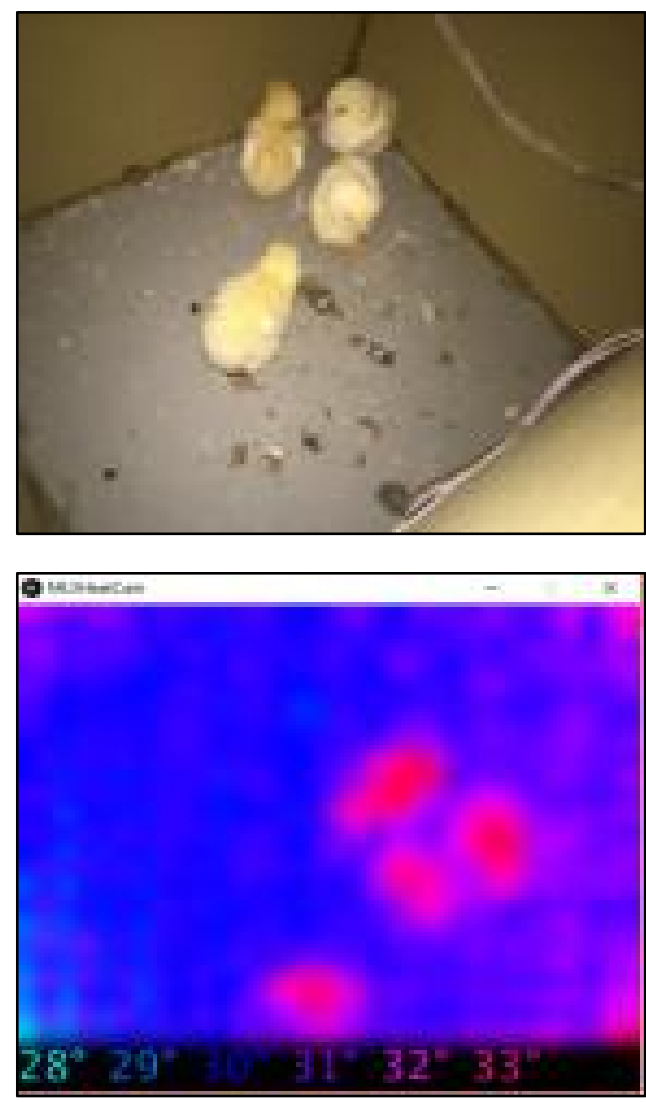

Gambar 11 Monitor Far Infra Red MLX90640 dengan 4 ayam
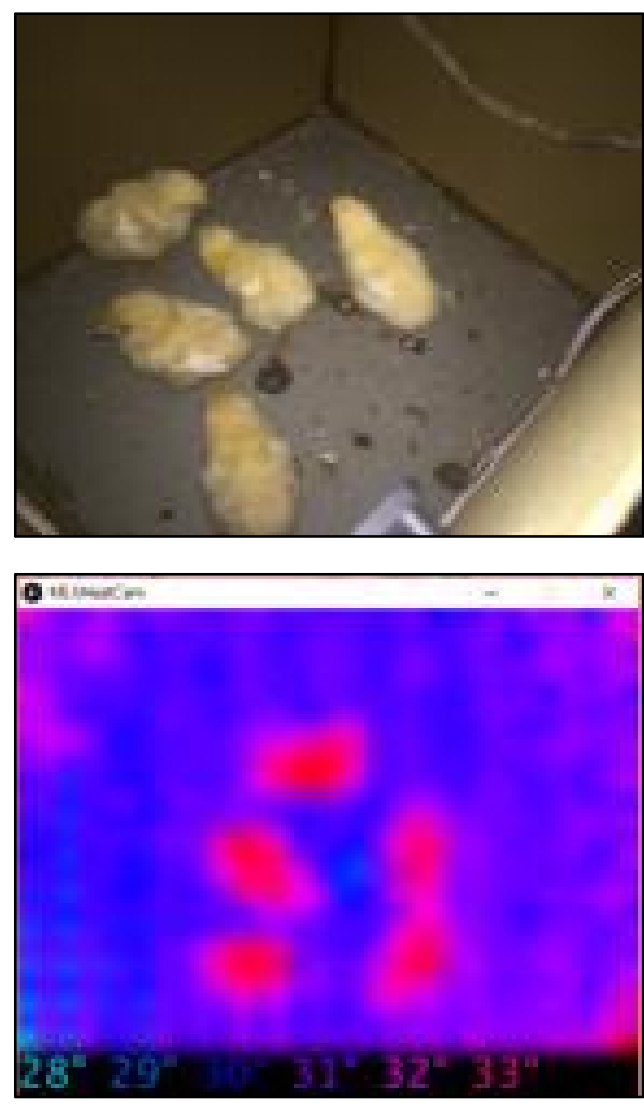

Gambar 12 Monitor Far Infra Red MLX90640 dengan 5 ayam 
Dari kelima percobaan diatas dapat dilihat bahwa sensor Far Infra Red MLX90640 bisa mendeteksi seluruh ayam yang berada dalam kandang ayam tersebut, mulai dari 1 ayam sampai 5 ayam. Pada percobaan diatas pun bisa dilihat posisi ayam berada disebelah mana dan dapat mendeteksi suhu ayam yang berada dalam kandang tersebut.

\subsection{Pengujian Wemos D1 Mini}

Pengujian wemos D1 mini dilakukan dengan tujuan untuk mengetahui kesiapan program yang telah dibuat. Langkah pengujian ini yaitu dengan mengupload program pada aplikasi Arduino IDE ke board wemos D1 mini dan menjalankannya.

Selanjutnya menghidupkan hotspot pada android yang telah disesuaikan id name dan passwordnya di program Arduino IDE, apabila langsung terkoneksi berarti wemos D1 mini berjalan dengan baik.

Tabel 1 Pengujian pada Wemos D1 Mini

\begin{tabular}{|c|c|c|}
\hline No & Pengujian & Hasil \\
\hline 1 & $\begin{array}{c}\text { Tegangan Wemos D1 mini Spesifikasi } \\
\text { pada datasheet : 5 V Pengukuran } \\
\text { dengan multimeter : 4.92 V }\end{array}$ & Baik \\
\hline 2 & Konektivitas wifi & Baik \\
\hline
\end{tabular}

\subsection{Pengujian Relay}

Pengujian relay bertujuan untuk mengetahui apakah koil relay dan kontak relay berfungsi dengan baik atau tidak. Pengujian ini dilakukan dengan memasukkan perintah untuk menyalakan relay baik itu relay 1 (lampu pijar 1), relay 2 (blower masuk), relay 3 (blower sirkulasi), relay 4 (blower keluar), dan relay 5 (mist maker / pelembab). sehingga dapat diketahui keenam relay tersebut sudah berfungsi dengan baik atau belum. Batas nilai suhu yaitu $24^{\circ} \mathrm{C}$ hingga $29^{\circ} \mathrm{C}$ dan batas nilai kelembaban yaitu $60 \%$ hingga $70 \%$. Perintah yang diberikan untuk suhu adalah apabila suhu kurang dari $24^{\circ} \mathrm{C}$ maka relay 1 dan relay 2 aktif/ON sementara relay 3, relay 4, relay 5 tidak aktif/OFF sedangkan apabila suhu lebih dari $29^{\circ} \mathrm{C}$ maka relay 4 aktif/ON dan relay 1 , relay 2 , relay 3 , relay 5 tidak aktif/OFF. Untuk perintah yang diberikan untuk kelembaban adalah apabila kelembaban kurang dari $60 \%$ maka relay 2 dan relay 3 aktif/ON sementara relay 2 , relay 4 , relay 5 tidak aktif/OFF sedangkan apabila kelembaban lebih dari $70 \%$ maka relay 5 aktif/ON dan relay 1 , relay 2 , relay 3 , relay 4 tidak aktif/OFF.

\section{Kesimpulan}

Setelah melakukan serangkaian kegiatan yang meliputi : Perancangan, Pembuatan alat, pengujian, dan analisa, maka didapatkan beberapa kesimpulan dalam tugas akhir ini, diantaranya yaitu :

1. Dengan menggunakan kandang ayam type clouse house maka peternak tidak perlu lagi untuk mengatur suhu/kelembaban secara manual.

2. Dengan adanya alat system monitoring ini dapat meingkatkan produktifitas ayam broiler dan hasil produksi ayam yang tepat waktu secara efektif.

3. Pada sensor suhu DS18B20 dan Sensor kelembaban DHT11 terdapat kesalahan nilai pembacaan atau error reading yaitu : sensor suhu DS18B20 paling besar itu 3,3\% dan untuk sensor kelembaban DHT11 paling besar itu 3,07692\%.

4. Data suhu kandang, kelembaban kandang, dan suhu ayam itu secara realtime atau secara terus menerus dikirim melalui wifi ke server.

5. Peternak pun bisa melihat data suhu kandang, kelembaban kandang, dan suhu ayam pada web.

\section{Daftar Pustaka}

[1] https://repository.ipb.ac.id/handle/123456789/696 93 diakses pada 4 mei 2019

[2] https://www.mouser.co.id/new/melexis/melexismlx90640-fir-sensor/ diakses pada 7 mei 2019

[3] http://docplayer.info/44211796-Pendahuluangambar-1-sensor-suhu-ds 18b20.html diakses pada 7 mei 2019

[4] http://riza-

electrical.blogspot.com/2012/07/lampupijar.html diakses pada 4 juni 2019

[5] http://www.automationindo.com/article/228/apaitu-blower\#.XMtB_IkzbIU diakses pada 11 juni 2019

[6] https://teknikelektronika.com/pengertiansensor-suhu-jenis-jenis-sensor-suhu/ diakses pada 11 juni 2019

[7] http://zonaelektro.net/sensor-suhu/ diakses pada 11 juni2019

[8] https://www.anakdagang.com/ragam-jeniskandang-ayam/ diakses pada 16 juni 2019

[9] https://id.wikipedia.org/wiki/Kandang diakses pada 16 januari 2019

[10] http://www.sinauarduino.com/artikel/esp8266/ diakses pada 27 juni 2019

[11] https://uswatun25.wordpress.com/2016/02/17/ modul-esp8266/ diakses pada 27 juni 2019

[12] https://embeddednesia.com/v1/tutorialnodemcu-pertemuan-pertama/ diakses pada 30 juni 2019

[13] https://hobiternak.com/7-pemanas-buatanuntuk-usaha-ayam-jawa-super-joper/ diakses pada 10 juli 2019 
[14] https://hobiternak.com/5-jenis-pemanasbuatan-pada-kandang-ayam-kampung-super/ diakses pada 10 Juli 2019

[15] http://www.peralatankandang.com/pendinginkandang/ diakses pada 15 Juli 2019

[16] https://rayendente.wordpress.com/2015/03/26/s ensor-inframerah/diakses pada 16 Juli 2019

[17] Agung Gregorius. 2019. PHP untuk Programmer Pemula. Yogyakarta : PT Elex Media Komputindo.

[18] Kadir Abdul. 2013. Panduan Praktis Mempelajari Aplikasi Mikrokontroler dan Pemerogramannya Menggunakan Arduino. Yogyakarta : CV ANDI OFFSET.

[19] Taufik Ikhwan. 2018. Komunikasi Data. Yogyakarta : GAVA MEDIA.

[20] Prasetya Bayu, Tamalluddin Ferry. 2014. Panduan Lengkap Ayam Broiler. Surabaya : Penebar Swadaya.

[21] Syahidwan. 2018. Tugas Akhir. Bandung. Universitas Langlangbuana 